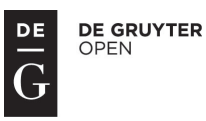

\title{
CARRots AND STICKS AS InCENTIVE MECHANiSMS FOR THE OPTIMAL INITIATION OF INSOLVENCY PRoCEEDINGS
}

\author{
Jaka Cepec ${ }^{1}$, Mitja Kovac ${ }^{2}$
}

\begin{abstract}
The pursuit of ex-ante efficiency in bankruptcy law has been widely discussed in recent law and economics literature. However, the exact incentive mechanisms inducing the optimal commencement of bankruptcy proceedings have generally been exempted from the current scholarly debate. Using the law and economics tools and comparative analysis, this paper seeks to identify insolvency-specific optimal incentive mechanisms, while using the general theory on carrots and sticks in legal regulations. The paper suggests the employment of mixed-sticks-and-carrots incentive mechanisms for managers' prompt proposals of insolvency proceedings as an optimal regulatory response. Moreover, the article provides comparative evidence that exclusive use of sticks or carrots in French, German, US, English, and Slovenian legal systems results in sub-optimal initiation of insolvency proceedings and may also induce adverse effects on prompt initiation.
\end{abstract}

\section{Keywords}

Corporate Insolvency, Trigger Mechanisms, Incentives, Efficiency, Comparative Insolvency Law, Carrots and Sticks

\section{Introduction}

Creating efficient incentives for the prompt initiation of insolvency proceedings is one of the most challenging and partially unexplored questions of modern insolvency law. One of the essential goals of bankruptcy law is the pursuit of ex-ante efficiency. The key element of ex-ante efficiency in bankruptcy law is an incentive mechanism that induces managers to promptly file a petition triggering a formal bankruptcy proceeding. Without such prompt initiation of insolvency proceedings, the financial and business deterioration of firms

\footnotetext{
${ }^{1}$ University of Ljubljana, Faculty of Economics, Kardeljeva ploscad 17, Ljubljana, SI - Slovenia; e-mail: jaka.cepec@ef.uni-lj.si.

${ }^{2}$ University of Ljubljana, Faculty of Economics, Kardeljeva ploscad 17, Ljubljana, SI - Slovenia; e-mai: mitja.kovac@ef.uni-lj.si.
} 
filing for insolvency might become so severe, that eventually the issue of ex-post efficient insolvency proceeding turns out to be completely irrelevant. Insolvency law and economics literature shows that, for various reasons, stakeholders in an unregulated environment lack efficient incentives for the prompt initiation of an insolvency proceeding. Hence, optimal managerial behaviour might be induced by legal rules through the employment of various carrots or sticks incentive mechanisms.

Our work contributes to the law and economics literature by considering the interrelationships between current incentive mechanisms for prompt insolvency initiation and by suggesting an extension of current general law and economic insights on carrots and sticks as powerful incentive mechanisms.

Coase (1960) and Wittman (1984), for example, show that, at the individual level, carrots and sticks have an equivalent marginal effect on incentives. However, although punishments and rewards are symmetrical ways to induce compliance with a single command, they differ fundamentally when it comes to multiple commands. Dari-Mattiacci and De Geest (2010), in their thoughtful article on carrots and sticks, suggest that, generally, the threat to punish (a stick) is more powerful than the promise of reward (a carrot) because, when parties comply, the former is not carried out and thus can be reiterated all over again (the multiplication effect), whereas rewards will have to be paid and thus are consumed with use. In other words, sticks are used up in the case of violation, whereas carrots are used up in the case of compliance. Scholars also argue that carrots are superior when it is not clear what the maximum level of performance is, and sticks are superior when the minimum is unclear (Lazear, 1995).

We show that the characteristics of currently used carrots and sticks as incentive mechanisms in insolvency law differ from the general incentive framework of carrots and sticks. Moreover, we also show that, even though combinations of incentive mechanisms used in the compared legal systems strongly differ, none really work efficiently. Hence, when carrots and sticks are used separately/individually, they have important disadvantages and employing only one of them might have a distortive effect on initiation incentives. Consequently, we argue that, due to poor results in the prompt initiation of insolvency proceedings in basically all compared legal systems, legal systems should use a variety of alternative carrots and sticks mechanisms (a combination of them, i.e. a mixed system) as complimentary instruments.

Our analysis of carrots and sticks rests on the narrowly defined, rational choice framework, which besides maximizing behaviour and market equilibrium, also comprises the principle of wealth maximization, where the measure for parties' maximizing behaviour is their willingness to pay (Shavell, 2004). We assume that legislators and agents are rational, wealth maximizing parties (Posner, 2011), that agents are fully informed about the content of legal rule, that legislators are not opportunistic (Wathne, Heide, 2000) but are benevolent, and that agents are risk averse (whereas legislators are risk neutral). Moreover, one should also note that we do not discuss any of the psychological or behavioural aspects, although we do not deny the importance of those aspects. 
Comparative illustrations are based on the comparison of the four representatives of major legal systems that represent three legal families (Zweigert, Kötz, 2004), namely England and the US as representatives of the common law family, Germany as a representative of the German legal family and France as a representative of the Roman legal family. We have also included Slovenia as the authors' home legal system.

However, two caveats should be issued in relation to the scope of this article. Namely, because it is impossible to cover all aspects of insolvency law, this article merely focuses on the optimal commencement of bankruptcy proceedings incentive mechanisms and omits any comment on the risk-shifting incentives of shareholders/managers in the vicinity of insolvency - this is beyond the scope of this article. Moreover, although other stakeholders might also be entitled to commence formal insolvency proceedings, our focus is on the debtor's managers.

This article is organized as follows. In Section II, we provide arguments on the importance of the ex-ante efficiency of insolvency law. Section III advances the problem of suboptimal incentives for the prompt initiation of insolvency proceedings and the arguments for lawmakers' intervention, whereas Section IV lists existing legal inducement mechanisms employed in current insolvency law enforcement procedures and offers comparative illustrations of English, US, German, French, and Slovenian insolvency law. Section V firstly offers a general framework of the carrots and sticks theory and continues with an insolvency-specific investigation of carrots and sticks as the optimal incentive mechanisms for the prompt initiation of an insolvency proceeding. Section VI concludes the paper by summarizing the key findings.

\section{Prompt initiation of insolvency proceedings as the main goal of ex-ante efficiency of insolvency law}

From legal and economic viewpoints, corporate insolvency law should minimize the social cost of corporate failings. An efficient insolvency law must address three general concerns. First, it should ensure that ex-post insolvency assets are allocated to their highest valued use (ex-post efficiency). Second, it must not create incentives for firms not in insolvency to engage in inefficient activities (ex-ante efficiency). Finally, it must accomplish the first two goals as efficiently as possible (Rasmussen, Skeel, 1995).

Ex-post efficiency is mainly concerned with the maximization of debtor's total value available to be divided between creditors, which can be achieved through an efficient insolvency proceeding. It raises questions about the relationship between reorganization and liquidation proceedings, the costs of the proceedings, the best way of selling the debtor's assets, especially the question of preserving the going concern value compared to the piecemeal selling of assets, etc. The basic standpoint of ex-post efficiency is that a firm should be reorganized, sold for cash as a going concern, or closed down and liquidated piecemeal, according to which option generates the greatest total value. ${ }^{3}$

${ }^{3}$ See more on ex-post efficiency: Cabrillo, Depoorter (2000); Hart (1999); White (2001); Rasmussen, Skeel (1995); Armour (2001); Jackson (2001); Baird (1996); etc. 
The main objective of insolvency law in the ex-ante sense is to provide optimal incentives and behaviour for debtors and their creditors before insolvency occurs, with the goal of minimizing the risk of loans and thereby lowering interest rates of debt financing. In the ex-ante sense insolvency rules are not intended to protect creditors because creditors can protect themselves. If the insolvency law is more debtor-friendly, creditors will need to have a stricter lending policy. However, the design of insolvency law affects firm value in an indirect sense, through the impact on incentives and behaviour of creditors and debtors. Correct incentives reduce the cost and improve access to debt financing (Marinč, Vlahu, 2011).

The main element of ex-ante efficiency is the problem of the untimely initiation of insolvency proceedings. Without prompt initiation of insolvency proceedings, the financial and business deterioration of firms filing for insolvency will be so severe that the issue of ex-post efficient insolvency proceeding might actually become irrelevant.

To resolve the question of prompt (timely) initiation, one should answer two separate questions. The first is the problem of defining the optimal insolvency trigger time and the second is the question of which incentive mechanisms ensure that stakeholders will comply with defined optimal insolvency trigger times.

The question of defining the right moment for the commencement of insolvency proceedings is beyond the scope of this paper. Conventional economic reasoning suggests that formal insolvency proceedings should be commenced once the greater of the going concern value or the liquidation value of a firm falls below the total of its liabilities. Since this test is difficult to apply in practice, an additional cash-flow test is often used: formal insolvency proceedings should commence if a firm is unable to pay its debts as they fall due (Eidenmüller, 2006). ${ }^{4}$ Our assumption will be that the efficient point for commencement of an insolvency proceeding is ex-ante given and hence any definition of a trigger mechanism should be easily ascertainable. Otherwise, the relevant stakeholders (creditors, managers and shareholders) will not be able to adjust their behaviour and courts will have no precise standard that can be adjudicated.

Since there is a broad consensus that far too often companies do not file until it is too late to save them and most of their value has been dissipated, the main focus of this paper is the system of incentives that will ensure timely commencement of insolvency proceedings (Warren, Westrbook, 2001). In order to address this triggering issue, we analyse the incentive stream generated by the employment of sticks and carrots as incentive mechanisms.

\section{Suboptimal incentives for prompt initiation of insolvency proceedings}

Filing for insolvency is a fairly clear sign that a company is in financial distress. It is a reasonable inference that the company is not likely to be in operation in the future. This ending of the informational asymmetry can be particularly harmful to the company. The debtor may have trouble finding buyers for its products because potential buyers may fear that the debtor will not be in a position to honour its promises. Managers and employees

\footnotetext{
${ }^{4}$ See more on this topic: Baird (1991); International Monetary Fund (1999); Armour (2001); etc.
} 
will be less willing to join the business. The debtor may also find it harder to collect money it is owed, as its debtors may simply fail to pay or impose bogus defences, thinking that repeat dealings with the debtor are no longer important and that their reputation will suffer little if they fail to pay a firm in insolvency (Jackson, 2001).

Insolvency always leads to a debtor's loss of control, partial or complete, over the assets and operations of a company and may hurt the business itself through loss of credit from suppliers and general reputational damage. Therefore debtors have a strong incentive to resist filing for insolvency. These disincentives, added to the natural optimism of an entrepreneur and the difficulty of admitting failure, makes it likely that insolvency will be sought only as a last resort (Warren, Westbrook, 2001).

As the company approaches insolvency, the concern arises that managers, will "gamble on resurrection" (Stiglitz, 2001). Since managers and shareholders on the edge of insolvency do not have much left to lose but can gain a lot if they can save the company, they have strong incentives for risk taking and accepting excessive risks with projects that have a low probability of success but potentially high rewards, and which could save the business. The equity cushion of a firm and the incentives for shareholders to pursue hazardous projects with a (potentially) negative net present value are inversely related. Such incentives are maximized once equity has been economically wiped out, but they are also significant in the (immediate) vicinity of insolvency.

Strong disincentives also exist for managers. Managers stand, in the event of insolvency, to lose their jobs, reputations, suffer big career setbacks, and face the possibility of loss of future earnings and therefore have an incentive to take a gamble in order to avoid that situation. Adding a potential threat of criminal or civil liability of managers on the emergence of insolvency only increases the perverse incentives to engage in overly risky activities; they seem to become overly optimistic and prepared to gamble, to rescue themselves from any potential liability that could occur if the company goes into an insolvency proceeding. Managers of an insolvent firm will substitute unjustifiably risky projects for safer, more profitable ventures, a phenomenon known as the "debt overhang problem" or as "overinvestment" (in risky projects) and "underinvestment" (in safer ones) (Adler et al, 2006).

All these "costs" are connected with the commencement of the insolvency act as disincentive mechanisms for stakeholders to initiate insolvency proceedings.

\section{Creditors rarely have any incentives for initiating insolvency proceedings}

As a group, creditors have no incentive to commence insolvency too early (in the sense that the debtor is still solvent). There are even more reasons to think that an individual creditor has much more incentives not to start a collective proceeding at all. When a creditor gets information about debtor's insolvency, the rational response of a creditor will be to try to collect first instead of waiting and starting the (collective) insolvency proceeding (Jackson, 2001). The attentive and aggressive creditor who is most likely to start the insolvency proceeding may be the one most likely to be paid in full if he pursues its individual remedies. The creditor shares the benefits of insolvency with all the other creditors but 
bears a disproportionate share of the costs (including sanctions if a court later finds that the creditor commenced the insolvency proceeding inappropriately). A creditor pursuing an individual remedy may have little to gain by forcing the debtor to commence a collective proceeding, even though that course might be in everyone's (collective) best interest (Baird, 1991). The fact that creditors have no incentives to file for insolvency is supported by the empirical evidence of US insolvency cases. Tabb (1997) shows that in 1997, 99 per cent of cases were voluntary petitions (proceedings initiated by debtors themselves. According to Kennedy et al (2000), out of the 1,436,964 insolvency cases filed in the calendar year of 1998 , only 847 were involuntary filings.

German statistical data on insolvency proceedings shows that in 2006, 88 per cent of cases were initiated by the debtor (voluntary petitions) (Euler Hermes Kreditversicherungs, 2006). In Slovenia, debtors initiate 88 per cent of all cases (Cepec, 2014). The incentive problem for initiating insolvency proceeding by creditors is known as the common pool problem or the prisoner's dilemma. ${ }^{5}$

\section{Incentives created by the legal system}

Since neither debtors (managers) nor creditors have any incentives for the timely commencement of insolvency proceedings, the incentives have to be created by law using either carrots or sticks inducement mechanisms. Before assessing incentive mechanisms imposed/generated by the law, we have to determine which stakeholder(s) are the most appropriate targets for applying the incentive mechanisms. Legal rules might target the debtor (its managers), creditors, or a third independent party (e.g. state, State Attorney, etc.). ${ }^{6}$

Due to asymmetric information, problem law and economic theory suggests that the focus on the incentives for triggering insolvency proceedings should be in the hands of the party who has superior information about the finances and the likely future of the business of the debtor and who will not expend resources to dispute the appropriateness of the filing (Warren, 1993). In most cases this party is the debtor (or its managers). The debtor is typically the only party with access to full information about its outstanding obligations, future business plans and income projections. While no one is a perfect decision maker, the debtor is usually best able to assess how successful the business is likely to be in meeting its continuing obligations and to determine whether insolvency provides an opportunity to enhance the value of the business (Warren, 1993). This is especially the case in closely held companies.

\footnotetext{
${ }^{5}$ Each creditor has an incentive to try to seize assets of the debtor, even if this prematurely depletes the common pool of assets for creditors as a whole. Although creditors as a group may be better off cooperating and working together to distribute the debtor's assets in an orderly fashion, each individual creditor has an incentive to race to grab his share. If he waits and others do not, there may not be enough assets available to satisfy his claim. The common pool problem in insolvency law was introduced by Baird and Jackson in the early '80s and has since become established as the main legal and economic reasoning for the existence of insolvency law. See: Jackson (1982); Jackson (2001); Baird, Jackson (1984); Armour (2001); Bowers (1992); Hart (1999); etc.

${ }^{6}$ The idea of voluntary insolvency was not introduced in England until 1825. The first federal insolvency statute in the United States, the Insolvency Act of 1800, allowed only involuntary insolvency, and it was not until 1910 that corporations could be brought before the insolvency court, voluntarily or involuntarily. See Picker (1992).
} 
In countries where banking financing is especially important, banks, as creditors, might also be well informed and could also be considered suitable initiators (Warren, Westbrook, 2001). But because creditors generally lack accurate information to make a sound and efficient decision about the appropriateness of an insolvency remedy, this paper will focus on the incentives for debtors and their managers. ${ }^{7}$

Eidenmüller adds that even though lawmakers traditionally and quite rightly focus on shareholders/managers with respect to setting incentives for the triggering of formal insolvency proceedings, jurisdictions also set such incentives for creditors. Depending on the relative treatment of creditors or creditor groups in insolvency, the incentives of these with respect to the filing decision differ. To give just one example, if a particular jurisdiction substantially curtailed secured creditors' rights in insolvency, such creditors will have a strong incentive to oppose the opening of formal insolvency proceedings (Eidenmüller, 2006).

\section{Carrots and sticks as incentive mechanisms for prompt initiation of insolvency proceedings}

Before applying a general carrots and sticks framework to the question of incentive mechanisms for prompt initiation of insolvency proceedings, this paper lists a set of existing legal inducement mechanisms employed in current insolvency law enforcement procedures. Moreover, this part also offers a brief assessment of English, US, French, German, and Slovenian insolvency legislation as a comparative illustration of the discussed inducement mechanisms.

\section{Carrots and sticks in insolvency law}

Insolvency law institutes that may be universally classified as carrots are: (a) the debtor in possession rule, (b) the deviations of the absolute priority rule, and (c) bonuses for managers for prompt initiation of insolvency proceedings. All three kinds of carrots are available only in financial reorganization proceedings.

Debtor in possession means that the management of the debtor who has filed for a formal financial reorganization procedure remains in office and continues to perform managerial tasks for the debtor's businesses. In other words, managers of the debtor can retain control over the company (and financial remuneration). Debtor in possession is considered a classical carrot and was traditionally used in the US insolvency system.

The absolute priority rule $(A P R)$ is a rule that insists that all creditors' claims have priority over shareholders' claims. Under APR, shareholders lose all claims on the company's assets unless all creditors are paid in full. A deviation of APR means, that even though not all creditors are paid in full, the shareholders can retain (preserve) a proportion of the asset value. The deviations of the absolute priority rule are commonly possible only in the reorganization proceeding, which means that managers, especially in closely held

\footnotetext{
${ }^{7}$ In some countries (e.g. France), the state is also eligible to begin a formal insolvency proceeding, but since third parties have no business incentives and even less information than the creditors and can also be seen only as complementary, we will not analyse the incentive mechanisms for triggering insolvency proceedings by third parties.
} 
companies, should be inclined to initiate the proceedings early with the hope of a successful reorganization proceeding with a possibility to retain at least a part of the equity. ${ }^{8}$

Pay to stay bonuses and pay to perform bonuses are forms of carrots according to which creditors agree to pay key managers additional rewards for staying in a business that is facing insolvency proceedings or that is already in the financial reorganization proceedings. Pay to perform bonuses are bonuses paid by the creditors to managers for speedy reorganization of an insolvent company. ${ }^{9}$

Inducement mechanisms that may be classified as sticks are: (a) civil damages (tort, civil liability), (b) professional disqualification and (c) criminal liability including misdemeanour.

Tort or civil liability means that managers are liable for damages to creditors if they do not promptly file for insolvency proceedings or start other measures required by law at the occurrence of insolvency.

Professional disqualification is a stick that prohibits liable directors from managing, administering or controlling any commercial business and any form of company which involves economic activity (see section English law and French law). This sanction is usually imposed by a governmental agency or court.

Misdemeanour and criminal liability are the strictest forms of sticks for the untimely initiation of insolvency proceedings. It means that the breach of managers' obligation to commence proceedings is seen as a misdemeanour or even as a crime which might be punished by a fine or even imprisonment. This is a stick traditionally used in German-based legal systems, for example in Germany and in Slovenia.

Sticks are typically used primarily or solely in liquidation proceedings. Of the legal systems compared in this article, only German and Slovenian insolvency systems use sticks (damages and misdemeanour) in financial reorganization proceedings, although in practice, sticks are never used in financial reorganization proceedings in Slovenia.

\section{A comparative legal analysis of carrots and sticks used as incentive mechanisms}

Comparative analysis concentrates on the comparison of the four representatives of parent legal systems that represent three legal families, namely England and the US as representatives of the common law family, Germany as representative of the German legal family and France as representative of the Roman legal family (Zweigert, Kötz, 2004). We also include Slovenia (German legal family) as the authors' home legal system. The first four legal systems are so-called "mature" or "parent" legal systems which have been extensively adopted or imitated by others, and hence the choice of comparison appeared to be "value-maximizing". Furthermore, for reasons of objectivity, scholarly curiosity, the lack of comparative literature and recent financial/restructuring/insolvency challenges

\footnotetext{
${ }^{8}$ White (2005) stated that shareholders in the US CH 11 proceedings, kept between ten and fifteen per cent of shares. Bharath et al (2007) stated that deviations of APR in the US are getting smaller and rarer. Until the '90s, the average retained shares were around 75 per cent of all shares, between 1990 and 2005, an average of about 22 per cent of all shares, and in between 2000 and 2005, only about 10 per cent.

${ }^{9}$ For a comprehensive review, see Skeel (2003), Listokin (2007) or Henderson (2007).
} 
in the development of Slovenian insolvency law, this paper also provides a comparative analysis of the optimal commencement of insolvency proceedings incentive mechanisms in the recently changed Slovenian insolvency law.

If there is one significant similarity between comparative legal systems of insolvency law in the question of incentive mechanisms then it might be the absence of effective devices to contain the risk-shifting incentives of shareholders/managers in the vicinity of insolvency (Eidenmüller, 2006). German scholars showed that in 2006 approximately $75 \%$ of German cases were initiated too late (Kramer, Peter, 2012). Another analysis in 2009 showed that $66 \%$ of cases were initiated too late (Euler Hermes Kreditversicherungs, 2006: 7). In England an assessment was made between liquidation officers and in their opinion more than $75 \%$ of cases were initiated too late (Finch, 2009). Similar conclusions, without empirical research, were also made for France (Weber, 2006). Data on Slovenian cases also show that the vast majority of cases were initiated much too late (Cepec, 2014).

\section{English law}

English insolvency law has traditionally been based on the assumption that, where a company becomes insolvent, it is usually due to a failure of management and prior owners and their venality or incompetence. Insolvency has been considered to be a disgrace, a stigma (Goode, 2011). The English system has had a strong bias towards creditors, which reflects a general social attitude that is inclined to punish risk-takers when the risks go wrong and side with creditors who lose out (McCormack, 2007). ${ }^{10}$ English insolvency law was traditionally considered more pro-creditor, but used neither carrots nor sticks. Goode (2011) stated that English law has had a long tradition (from the mid-19th century onwards) of indulgence towards the directors of failed companies and that good faith, honesty and subordination of a director's own interests to those of his company have otherwise always been required, but the level of prudence, care and skill expected of a director in the conduct of the company's business has generally been low. He also states that public pressure and outrage about the business practices of English managers and their "ease" on bankrupting the companies resulted in the legislating of sticks into English insolvency law. The major sticks in English Insolvency law are the wrongful trading rule and disqualification of directors.

Under the wrongful trading provision contained in section 214 of the Insolvency Act 1986 , once a director or shadow director knows or ought to have concluded that there is no reasonable prospect that a company would avoid going into insolvent liquidation, they must take every reasonable step with a view to avoiding potential loss to company creditors. ${ }^{11}$ Under the Company Director Disqualification Act 1986, the UK Insolvency Service may disqualify a person from being a director for a specified period of time

\footnotetext{
10 See also Payne (2014) or Goode (2011).

11 Section 214 only sanctions wrongful trading in extreme cases. Firstly, directors are liable only if a company has gone into insolvent liquidation: it is not sufficient that the company has become insolvent. Secondly, there is no liability if a prudent director would have concluded that a reasonable prospect existed to avoid the insolvent liquidation of the company. For example, a 20 or 30 per cent chance is arguably such a reasonable prospect. There is not much case law on section 214. See also Eidenmüller (2006).
} 
if they are guilty on one of the statutory grounds for disqualification. Disqualification makes it unlawful without permission from the court to act as a director. The period of disqualification is between 2 and 15 years, depending on the grounds of disqualification. ${ }^{12}$ There are three distinct categories of conduct which may, and in some circumstances must, lead the court to disqualify persons from being involved in the management of companies. These categories are: (a) General misconduct in connection with companies ${ }^{13}$, (b) Disqualification for unfitness ${ }^{14}$ and (c) other cases for disqualification (fraudulent or wrongful trading; undischarged bankrupts acting as directors and failure to pay under a county court administration order).

English insolvency law did not traditionally make use of carrots as incentives for promptly commencement of insolvency procedures, but at least with the reforms brought about through the Enterprise Act in 2002, the English system is trying to promote corporate reorganization and consequently might be more favourable towards carrots (McCormack, 2009).

With regard to carrots, English insolvency law disfavours the debtor in possession rule, ${ }^{15}$ does not use bonuses, but allows contractual deviations from the absolute priority rule. This commonly happens within the so-called pre-pack administration procedure (Payne, 2014). ${ }^{16}$

\section{American law}

In the US system, management has no general duty to file for an insolvency proceeding upon the occurrence of insolvency. This means that the US insolvency system has more or less no sticks if management (directors) fails to put the interests of creditors first by filing timely insolvency proceedings. There is, however, the general law on directors' duties and in a growing number of US cases, the courts have held that managerial allegiance must shift from the shareholders to the creditors when a company approaches insolvency (McCormack, 2007). ${ }^{17}$ But, on the other hand, the Delaware Supreme Court rejected this notion by holding that officers and directors do not necessarily owe fiduciary duties to creditors of a company in the zone of insolvency. Those creditors cannot bring breach of fiduciary duty actions to recover individually, but may bring derivative claims on behalf of the corporations for such a breach. Creditors cannot hold directors liable for prolonging the lifespan of an insolvent corporation and worsening its financial state. Hence, so long as directors adhere to their fiduciary obligations, they can continue to operate and pursue

\footnotetext{
12 The Company Directors Disqualification Act 1986, s. 6(4). For an extensive analysis, see Goode (2011).

${ }^{13}$ A conviction for an indictable offence in connection with the promotion, formation, management, or liquidation of a company or with the receivership or management of a company's property; persistent breaches of companies legislation in relation to provisions which require any return, account, or other document to be filed with, or notice of any matter to be given to, the registrar; fraud in connection with winding up etc.

${ }^{14}$ The disqualification of the director of a company, which has become insolvent, who is found, by the court, to be unfit to be a director.

${ }^{15}$ In an older paper, Moss (1998) states that having a debtor-in-possession regime could be equated with leaving an alcoholic in control of a pub.

${ }^{16}$ See also Madaus (2013).

${ }^{17}$ For example, see Federal Deposit Insurance Corp v Sea Pines Co (1982) 692.
} 
business strategies when a company is insolvent without fear of liability to creditors under a standard of review other than the business judgment rule (Shu-Acquaye, 2011). ${ }^{18}$ This means that "only" the business judgment rule applies and the managers only have to take care that they are not engaging in projects with obviously excessive risk (Eidenmüller, 2006).

US insolvency law incentives for timely commencement of insolvency proceeding are built on carrots and are used in reorganization ( $\mathrm{Ch}$. 11) proceedings. The carrots can be summarized into: a) rules on the automatic stay (11 USC 362), b) the debtor-inpossession system (11 USC 1104, 1107) and c) the exclusivity period for managers to file the reorganization plan (11 USC 1121). A very important carrot in Ch. 11 is also d) the possibility of violating the absolute priority rule, which allows current equity holders to remain shareholders after the financial reorganization even though not all creditors were fully repaid (for the rule itself, see 11 USC 1129(b)).

In the last few decades, "pay to stay" and "pay to succeed" agreements have become increasingly important (Skeel, 2003). These "pay to stay" and "pay to succeed" contracts are a new form of contractually-based carrots, concluded between the old managers and creditors, who are willing to pay (reward) managers for their speedy and efficient conduct in the Chapter 11 reorganization proceedings.

\section{German law}

German insolvency law relies heavily on sticks to ensure prompt commencement of insolvency proceedings. It provides both tort and the criminal liability of managers for the breach of their duty to commence a proceeding in a period of three weeks after the occurrence of insolvency. ${ }^{19}$

A carrot in the form of the deviation of the absolute priority rule was used as an absolute rule until the insolvency law reform in $2012 .{ }^{20}$ The position of the equity holders in the reorganization proceeding (Insolvenzplan) had to be left immutable, according to the rules provided for by company law (Madaus, 2013). This changed importantly in 2012 and the new "version" of the German corporate reorganization (Insolvenzplan) now enables only contractual deviations from the APR rule, as the deviation is possible only if the creditors vote for a reorganization plan, which can deviate from the absolute priority rule. ${ }^{21}$

On the other hand, all other carrots were non-existent until the reform in 2012. The reform introduced the possibility of a debtor in possession restructuring proceeding (Eigenverwaltung) that enables managers to stay in position during the negotiation for a financial reorganization plan. The debtor in possession proceeding is possible only if the court

\footnotetext{
${ }_{18}$ For case law, see Credit Lyonnais Bank Nederland, N.V. v. Pathe Commc'ns Corp., No. Civ. A. 12150, 1991 WL 277613; Production Resources Group, L.L.C. v. NCT Group, Inc 863 A.2d 772 (Del. Ch. 2004) and finally North American Catholic Educational Programming Foundation, Inc. v. Gheewalla No. 521, 2006, 2007 WL 1453705 .

${ }^{19}$ See par. 15a InsO, par. $64 \mathrm{GmbH}$ Gesetz and par. 93 Aktien Gesetz.

${ }^{20}$ Law for the Further Facilitation of the Restructuring of Businesses (Gesetz zur weiteren Erleichterung der Sanierung von Unternehmen - ESUG).

${ }^{21}$ The Insolvenzplan has to be accepted by all groups of creditors and in each group by a double majority, namely the majority of creditors that represent the majority of debt in each group of creditors.
} 
decides that it is to be expected that the Eigenverwaltung will not lead to a delay in the proceedings or other disadvantages to the creditors. ${ }^{22}$ Germany insolvency law does not use any bonuses for the prompt initiation of insolvency proceedings.

\section{French law}

French insolvency law is considered one with the most rescue-oriented systems. The goal of the French system is not merely to facilitate reorganization, but to encourage it, through early interventionist mechanisms that force or strongly encourage businesses to seek rehabilitation early enough that businesses and jobs are not lost. The French system favours saving job-generating enterprises at almost any cost (Martin, 2005).

French law traditionally relies heavily on sticks to create incentives for the timely commencement of insolvency proceedings. Recent reforms have considerably strengthened the range of pre-insolvency proceedings, namely le mandat ad'hoc, la conciliatio and sauvegarde and introduced two new procedures (sauvegarde financière and rétablissement professionnel).$^{23}$ The basic characteristic of the reforms, considering the question of incentives, is the debtor in possession principle, which is considered an important carrot. Directors in France are subject to "draconian personal liability" for serious business mistakes that lead to the insolvency of the company. Engaging in risky ventures, borrowing imprudently or similar actions can lead to the personal liability of management, and it is not uncommon for the insolvency of a company to lead to the personal insolvency of its managers (Westbrook et al, 2010). Directors can also face civil liability, which is similar to the UK Company Directors Disqualification Act. Guilty directors will be prohibited from managing, administering, or controlling any commercial business and any form of company which participates in economic activity. ${ }^{24}$ The maximum period for which personal insolvency or prohibition from managerial activities may be ordered is 15 years. ${ }^{25}$

\section{Slovenian law}

Up until 2010, the Slovenian Insolvency Act used carrots and sticks as incentives for managers to promptly file for an insolvency proceeding. Carrots were used in the financial reorganization proceeding and were similar to the US Chapter 11 incentives. After filing for the financial reorganization proceedings, the automatic stay was activated, managers kept their positions (the debtor-in-possession system of financial reorganization proceedings), ${ }^{26}$ only managers could file for the financial reorganization proceeding and they had the exclusive power to propose and amend the reorganization plan. But the strongest carrot was the more or less complete omission of the absolute priority rule for shareholders in the

\footnotetext{
${ }^{22}$ InsO, par. 270. German legislator and insolvency experts were traditionally hostile to the idea of the debtor in possession system of financial reorganization proceedings.

${ }^{23}$ Reforms were made in 2005, 2008, 2010 and also in 2014. For more on these reforms, see Omar (2014).

${ }^{24}$ Article L. 653-2 of the French Commercial Code.

${ }^{25}$ For a thorough and precise insight into the liabilities of French managers in the case of corporate insolvency, see Sorensen, 2013.

${ }^{26}$ Empirical evidence shows that more than $75 \%$ of managers kept their position after a successful financial reorganization.
} 
financial reorganization proceeding, meaning that the financial reorganization proceeding more or less consisted of a debt discharge and/or extension of the maturity of repayment of unsecured creditors. Debt to equity transformation was optional and to the discretion of the debtor himself. If the proposal for financial reorganization (debt discharge) was confirmed by creditors whose claims represented 60 per cent or more of the total unsecured nonpreferential debt, ${ }^{27}$ the plan was accepted. Old equity shareholders and managers did not lose anything. They remained shareholders in the reorganized company and managers kept their jobs.

The Insolvency Act also used sticks, as managers were liable for damages to creditors if they did not promptly file for an insolvency proceeding or start other measures defined by law at the occurrence of insolvency. ${ }^{28}$ Under the Insolvency Act, managers are also liable for a misdemeanour if they do not promptly file for an insolvency proceeding or start other measures defined by law at the occurrence of insolvency. The fine is between 2,000 EUR and 10,000 EUR.

Even though the Slovenian Insolvency Act introduced both carrots and sticks as incentive mechanisms, less than $10 \%$ of all insolvency cases started as a financial reorganization case. The vast majority, more than $90 \%$ of cases, started as liquidation (Chapter 7) proceedings and in more the $80 \%$ of those cases, the companies did not have enough assets to even pay for the insolvency costs, so they were liquidated without a distribution of assets to creditors (Cepec, 2013).

In the middle of the global financial crisis, the Slovenian parliament started to make essential changes to the Insolvency Act. In just three years, from 2010 to 2013, the Slovenian Insolvency Act shifted from an extremely debtor-friendly system to a creditorfriendly system. The reform in 2010 enabled the creditors to make an increase in share capital from new contributions without the consent of debtor's shareholders. The reform of 2010 was just an outline of the legislator's real reform in 2013. The reform in 2013 introduced the absolute priority rule with no exceptions, enabling creditors to make a forced debt to equity swap, transforming part or all of the debt into equity without the consent of the debtor's shareholders. ${ }^{29}$ This means that the creditors in the reorganization proceeding can expropriate the old shareholders and change management. The financial reorganization proceeding can now also be proposed by the financial creditors, who can also prepare the reorganization plan or make changes, if the plan was proposed by the debtor. The legislator more or less eliminated all incentives for management and/or shareholders to file for the commencement of insolvency proceedings.

The basic idea of the reform was to change the incentive focus from the debtor and its managers, who obviously did not "react" to the incentives they had, to financial creditors

\footnotetext{
${ }^{27}$ Since secured and preferred debt could not be discharged, those creditors could not vote and their claims were not included. See Zajc, Cepec, 2012.

${ }^{28}$ Members of the management shall be wholly or partially relieved of their liability for the damages referred to in the first paragraph of this Article if they can prove that the whole or a part of the damages were caused by events or the actions of other persons whose prevention, avoidance, or limitation of their adverse consequences was beyond the management's capacity, despite their having acted with the professional due diligence of the corporate finance and corporate governance profession (Article 42(4)).

29 The forced debt to equity also allows a simplified reduction in subscribed capital to zero.
} 
(banks). As a typical civil law country, banks are by far the most important creditors in the Slovenian economy. The legislator obviously believes that the shift of the position of management and shareholders in the financial reorganization proceedings will give enough incentives to the banks to start prompt filing for the commencement of the financial reorganization proceedings. As the reform only entered into force in December 2013, we cannot see or comment on any results yet. ${ }^{30}$

\section{Carrots and sticks - a general framework}

After the comparative illustration and identification of debtors and managers, as the primary focus of our investigation, this section turns towards a synthesis of law and economics scholarship on the general framework of carrots and sticks inducement mechanisms. Moreover, later on, it proceeds with an analysis of insolvency-specific carrots and sticks as the optimal incentive mechanisms for prompt initiation of an insolvency proceeding.

While there is some confusion in legal literature on the exact meaning of carrots and sticks, law and economics literature offers a precise definition. Namely, carrots and sticks are both transfers of wealth that induce the citizen/agent to comply with a rule. A carrot is a payment to the citizen/agent (in broadly defined lawmaker or principal) that is made if the citizen/agent has been monitored and found to be complying (Dari-Mattiacci, De Geest, 2013), whereas a stick is a payment by the citizen (or agent) to the lawmaker (or principal) that is made if the citizen has been monitored and found to be in violation. But can carrots and sticks indeed be objectively defined or do they represent two sides of the same coin?

Some authors have argued that this distinction is only a matter of framing, because carrots can be rewritten as algebraically identical to sticks and vice versa. Coase (1960) and Wittman (1984), for example, show that at the individual level a carrot and a stick have an equivalent marginal effect on incentives. ${ }^{31}$ As an illustration of their argument, one may consider a delivery contract with a price of 100 EUR and a penalty for late delivery of 9 EUR (applied with probability $p=1$ ). This contract can be rewritten as one with a price of 91 EUR and a bonus for timely delivery of 9 EUR. In both cases the performing party receives 100 EUR if he delivers on time and 91 EUR if he delivers late. Prima facie, these two regimes might seem equivalent.

However, De Geest and Dari-Mattiacci show that Coase and Whitman's argument holds only if monitoring is non-probabilistic (i.e. if it occurs with a probability equal to 1) (DariMattiacci, De Geest, 2013). If the probability of monitoring is less than 1, than payoffs under carrots and sticks are no longer algebraically identical. Namely, one should consider a hypothetical example where the citizens can only be monitored in 10 per cent of cases.

\footnotetext{
30 The development of the Slovenian insolvency law in the last 23 years can summed up as the path of a paradigm shift from a debtor-friendly regulation to a creditor-friendly regulation. This has happened as a result of public pressure in times of financial crisis, on the basis of the belief that most insolvent debtors became insolvent due to fraud or abuse of corporate law and, as a consequence, do not deserve to have any active role in the insolvency procedure.

${ }^{31}$ See also Cooter and Ulen (2004).
} 
"A penalty contract with a base price of 100 EUR now needs a penalty with a magnitude of 90 EUR (because it is applied to only 10 per cent of violators); a bonus contract with a base price of 91 EUR now needs a bonus of 90 EUR (because it is paid to only 10 per cent of the compliers). This means that compliers will receive 100 EUR under a penalty regime, while under a bonus regime they will receive either 91 EUR (the base price, in case of no monitoring) or 181 EUR (the base price plus the 90 EUR bonus, in case of monitoring). Under a penalty regime, violators will receive either $100 \mathrm{EUR}$ (the base price in case of no monitoring) or 10 EUR (the base price minus the 90 EUR sanction, in case of monitoring), while they will always receive 91 EUR under a bonus regime. While the payoffs are equal in expected terms, they are different in real terms, and therefore the risk allocation is different (the penalty contract is risky for breaches while the bonus contracts is risky for performers)." 32

Moreover, Dari-Mattiacci and De Geest also identify the multiplication effect, which might be offered as a significant argument against the exclusive employment of carrots as the sole inducement mechanism (Dari-Mattiacci and De Geest, 2010). In this respect one should note that, although punishments and rewards are symmetrical ways to induce compliance with a single command, they differ fundamentally when it comes to multiple commands. Dari-Mattiacci and De Geest 2010) suggest that the threat to punish (a stick) is more powerful than the promise to reward (a carrot) because, when parties comply, the former is not carried out and thus can be reiterated all over again (the multiplication effect), whereas rewards will have to be paid (by someone) and thus are consumed with use. ${ }^{33}$ In other words, sticks are used up in the case of violation, whereas carrots are used up in the case of compliance. Thus, sticks appear to be a more efficient means of inducing people to comply with legal rules or social norms because they are actually not meant to be applied (minimization of transaction costs and risks) and may cause fewer unintended distributional distortions. One should also note that sticks are only multipliable if agents behave non-cooperatively. ${ }^{34}$ On the other hand, Lazear considers the effect of drafting difficulties, arguing that carrots are superior when it is not clear what the maximum level of performance is, and sticks are superior when the minimum is unclear (Lazear, 1995). Furthermore, De Geest and Dari-Mattiacci (2013) also identify a tendency, in modern legal systems, towards the increasing use of carrots. In their analysis they consider transaction costs, risk costs, and the costs of distributional distortions. As to the transaction costs, they make a distinction between ex-ante monitoring costs (which are incurred ex-ante before citizens are actually monitored) and ex-post processing costs (the costs of actually paying a carrot or collecting a stick). ${ }^{35}$ As to the risk costs, they assume that citizens are usually

\footnotetext{
32 To calculate the expected value, one adds the payoffs from each possible outcome discounted by its probability. For example, if a violator has a 10 per cent chance of earning 10 EUR and a 90 per cent chance of earning $100 \mathrm{EUR}$, the expected value is: $(10) *(0.1)+(100) *(0.9)=91$ EUR.

${ }^{33}$ This also implies that the use of carrots (i.e. salaries) requires an enormous amount of resources (as carrots are consumed with use) allocated to judiciary rewards (payment) which might be, due to the high monitoring costs, in this instance of judicial performance, entirely wasted (pure waste of resources).

${ }^{34}$ The multiplication effect is based on the exploitation of non-cooperative behaviour in the population and is a tool that makes sticks more powerful and enforcement based on sticks, cheaper; id.

35 Ex-ante (monitoring) costs increase with the probability of monitoring and are the same under the two regimes;
} 
risk averse and that monitoring levels lower than 100 per cent impose risk-bearing costs on society. As to the distributional distortion costs, they argue that under some conditions the effect of a penalty or reward may be that some citizens become poorer or wealthier than others. They actually show that carrots might be superior to sticks in two cases, namely in the instances where the legislator faces specification problems, ${ }^{36}$ or in the instances where the legislator needs to require significantly greater efforts from some citizens than from others. ${ }^{37}$ They also argue that in simple settings, sticks are superior, because they are (as already stated) not meant to be applied (minimization of transaction costs and risks) and they also cause fewer distributional distortions when the managers/creditors are sufficiently homogeneous with respect to effort costs. But the effect of those sticks might be lost when managers/debtors are heterogeneous with respect to effort costs (Dari-Mattiacci and De Geest, 2010). In those cases, sticks actually punish citizens who are unable to comply with the rule at reasonable cost and this also generates wasteful transaction costs and risk costs. Furthermore, when a legislator is fully informed about each manager's effort cost, carrots can be superior when the demanded effort costs vary among agents. In addition, carrots should be also applied when one encounters a singling-out danger, which is the case when rules are less general and more individualized (i.e. when high efforts are required from some individuals but not from others). Yet, the sticks should be applied in cases where there are no specification problems (i.e. when it is clear who is, for example, in the best position to acquire information about the firm's financial distress) ${ }^{38}$ and when such a stick would not lead to singling-out problems (e.g. where the required effort to begin insolvency proceedings is equally distributed among debtors/managers/shareholder) (Dari-Mattiacci and De Geest, 2010). ${ }^{39}$

They identified seven fundamental differences between carrots and sticks. Namely, (a) a carrot is applied upon compliance, a stick, upon violation; (b) carrots incentivize by effectively rewarding while sticks incentivize only by threatening; (c) carrots generate (ex-post) transaction costs in case of compliance, sticks in case of violation; (d) under carrots, all non-monitored citizens receive the same treatment as monitored violators, whereas under sticks, all non-monitored citizens receive the same treatment as monitored compliers; (e) carrots create risks for compliers, whereas sticks create risks for violators;

conversely, ex-post (processing) costs are the costs of actually paying a carrot or imposing a stick. These include not only payment costs in a strict sense, but also collecting evidence ex-post, determining the magnitude of the carrot or the stick and informing the citizen that a carrot or a stick will be applied. Ibid.

${ }^{36}$ This means that she does not know what to expect from each individual citizen. In those cases, sticks are likely to punish citizens who are unable to comply with the norm and likely to cause wasteful transaction costs, risks, and undesirable wealth changes (De Geest and Dari-Mattiacci, 2013).

37 If one would apply sticks in such conditions, they would have to be overly broad - in terms of the citizens from whom it requires an effort and the tasks it requires from citizens. In such cases, sticks would cause significantly unintended distributional distortions - artificially impoverishing those from whom much is required - making carrots superior (De Geest and Dari-Mattiacci, 2010).

${ }^{38}$ The »should have known « criterion is actually a tool to overcome evidence problems and also means that there is only such a duty when there are no specification problems.

${ }^{39}$ However, if one were to have difficulties (asymmetric information problem) specifying when a CEO should commence (optimal timing of starting insolvency proceedings) with insolvency proceedings, then due to these specification problems, carrots become a superior inducement mechanism. 
(f) only carrots have a built-in compensation mechanism; and finally (g) individualized and general carrots have different distributional effects for compliers, while individualized and general sticks have the same distributional effects for compliers. (Dari-Mattiacci and De Geest, 2010).

Moreover, if we would have a homogenous society with a fully informed benevolent legislator, then sticks would appear to be the optimal inducement mechanism. In the instance where the legislator would be fully informed but the costs of each citizen's effort would vary, then one should employ carrots as an optimal mechanism (Dari-Mattiacci and De Geest, 2010). On the other hand, if citizens have different effort costs, then this would represent an instance where carrots would represent an optimal inducement mechanism. Another case for carrots would also be an instance where the lawmaker has no information on the citizens' individual effort costs.

Finally, De Geest and Dari-Mattiacci (2013) propose a set of normative guidelines for the use of carrots and sticks. Their first normative guideline is that in simple settings sticks are superior because they are not meant to be applied and thus minimize transaction ${ }^{40}$ costs and risks. Their second guideline suggests the employment of carrots in cases of specification problems (i.e. when the lawmaker does not know what to ask from each citizen/agent/principal). ${ }^{41}$ Thirdly, carrots should be employed in the case of singling-out problems (i.e. where the lawmaker needs to ask for substantially higher efforts from some citizens/agents). This would be the case when rules are less general and more individualized (when, for example, higher standards are imposed on some individuals but not on others) (Dari-Mattiacci and De Geest, 2013). ${ }^{42}$

\section{Specific carrots and sticks insolvency issues}

Previous specific literature on incentive mechanisms for the prompt initiation of insolvency proceedings is heterogeneous and authors have very different opinions about the superiority of carrots or sticks. Authors are either quite strong supporters or opponents of either carrots or sticks, but generally the previous literature is more in favour of carrots, as it suggests that sanctions might be problematic because they impose risks on shareholders/managers, the limited wealth of managers might inhibit the effectiveness of financial sanctions and they might also impose needless transaction costs (processing, monitoring,

\footnotetext{
$40 \gg$ In addition, sticks cause fewer distributional distortions when the citizens are sufficiently homogenous with respect to effort costs. Yet if citizens are heterogeneous with respect to effort costs than sticks may punish citizens who are unable to comply with the rule at reasonable costs - if they are applied in such setting they generate transaction costs and impose needless risk costs. «

${ }^{41}$ It is suggested to employ carrots when there are specification problems, when it is not clear who exactly should do what (e.g. who should invent, compose, rescue, disclose information). In such cases, a stick regime would simply have to be overbroad (both in terms of the citizens from whom it requires an effort and the tasks it requires from the citizens).

42 They also note that the magnitude of the individual effort cost itself is not sufficient for the singling-out danger; unequal treatment of individuals is also required (for instance, if the law requires all males to serve in the army, the law requires large effort costs, but because all families contribute more or less equally, there are no significant distributional distortions).
} 
and enforcement costs). Nonetheless, sticks are probably also necessary to contain the riskshifting incentives of managers and shareholders. Rewarding shareholders and managers even if they did a bad job, just because they promptly initiated insolvency proceeding, shifts even more risks towards creditors (Eidenmüller, 2006).

Baird (1991) argues that imposing a legal duty on the managers to begin insolvency proceedings is likely to have little effect because there would be no effective sanction for a failure to meet it. The firms that are most apt to need reorganization in insolvency are closely held and much of the personal wealth of the managers may be tied up in the firm. If managers make decisions that run contrary to the interests of the creditors as a whole, there may be nothing to be done about it after the fact. The managers, like the firm, may be insolvent. Imposing a legal duty on someone who is judgment-proof is not effective if the parties to whom the duty is owed are diverse and not able to act in concert before the fact (Baird, 1991). ${ }^{43}$ Finally, imposing a duty on the managers of a firm to begin an insolvency proceeding at the appropriate time would be all but impossible to enforce (prohibitive transaction costs). The moment at which a collective proceeding becomes in everyone's interest, is hard to identify even for someone intimately familiar with a firm and its financial condition. A judge does not have knowledge of the condition of the firm, nor the skills needed to use this knowledge. Even after the fact, no one has a way to determine precisely the "right" time to file an insolvency petition (Baird, 1991). Eidenmüller (2006) adds that sticks impose additional risk on managers and that sanctions must be enforced, which results in additional costs.

The IMF (1999) stressed that, if rehabilitation proceedings mirrored liquidation proceedings in terms of the degree of control that the debtor is given over the enterprise, such an approach would clearly undermine any incentives for the debtor to voluntarily make use of rehabilitation proceedings. Sticks have the disadvantage of possibly discouraging management from attempting an out-of-court restructuring agreement, out of a fear that any delay in beginning formal proceedings may result in personal liability. But on the other hand, imposing liability upon officers and directors for "trading while insolvent" can have an advantage because it forces debtors to initiate proceedings at an early stage. Such early filings increase the chances for rehabilitation or, at a minimum, protect creditors' interests by preventing the further dissipation of the enterprise's assets. If a country chooses not to rely on penalties as a means of forcing debtors to begin proceedings early, it may find it necessary to encourage debtors to do so through the creation of commencement incentives (IMF, 1999).

The weakness of giving a cash bonus to managers (or to a creditor or anyone who starts an insolvency proceeding at the optimum time) may lie in the inability of the court to determine after the fact when the insolvency petition should have been brought and how much difference bringing the proceeding at the right time makes. One could not, of course, give the managers a flat fee. The amount they receive must be based on how much of the firm's value they preserved by bringing the insolvency petition at the appropriate time (Baird, 1991).

${ }^{43}$ See also Eidenmüller, 2006. 
Research by Adler et al (2006 and 2013) has shown that managers react to changes in the insolvency law. They have observed deterioration in the financial and economic health of firms at the time of their insolvency filing when the carrot, in the form of debtor in possession, was changed (abandoned). ${ }^{44}$

Frouté (2007) notes that sticks act pro-cyclically. This means that at a time when the company is doing well, sticks encourage management to continue to work well, but when a company gets into trouble, sticks encourage them to start accepting excessively risky projects. Carrots work in just the opposite way. At a time when the company is in a good financial condition, carrots encourage managers to take on excessively risky business, at a time when the debtor is in financial difficulty, it encourages more restrictive treatment, knowing that they can still hope to keep a part of the company. This means that carrots work counter-cyclically.

Picker (1992) concluded that the choice between carrots and sticks should be guided by the ex-ante consequences of the different rules. Penalties that do not offer direct benefit to creditors, such as fines, imprisonment, or disqualification may just dampen entrepreneurial initiative. Unless we think too many projects are started, we might be better served by a bonus scheme that had the same effect on inducing petition filings. Penalties that do run in favour of the creditors may also be less efficient than bonuses if manager/shareholders are systematically more risk averse than creditors. A bonus scheme acts as insurance, while a penalty scheme exacerbates the substantial losses already suffered by poorly diversified insiders. Monetary penalties also become meaningless if the manager is insolvent themselves. Another benefit of carrots is that managers seek carrots, while they run from sticks.

Bebchuk (2002) and Eidenmüller (2006) argue that sticks (sanctions) might, at the end of the day, still be necessary in order to contain the risk-shifting incentives. ${ }^{45}$

\section{Optimal application of carrots and sticks in insolvency law: insolvency-specific carrots v. sticks framework}

In general theory, the distinction between monetary carrots and sticks, if the probability of monitoring equals 1 ( $p=1$ ), is only a matter of framing, as carrots can be rewritten as algebraically identical to sticks and vice versa. Therefore we firstly analysed if carrots and sticks in insolvency law are in fact just two sides of the same coin.

Since financial and accounting reports have to be analysed in each insolvency case (liquidation or reorganization), due to the insolvency procedure itself, the probability of ex-post monitoring is very close to $1(p=1)$. As additional monitoring costs (transaction costs) of complying with the mandatory rules for prompt initiation of insolvency proceedings

\footnotetext{
44 They analysed the US change from the pre-2000 DIP (Debtor in Possession) period as compared to the SPIP (Secured Party in Possession) period after 2000 in $\mathrm{CH} 11$ proceedings.

45 Eidenmüller: "Rewarding shareholders with an equity share in the reorganized firm does nothing to address these incentives. Violations of absolute priority in insolvency, for example, allow the beneficiaries of such violations to shift more risk to creditors (where beneficiaries gain something even if the bad state of the world materializes), and this risk consequently leads to a higher interest rates which further increases the risk-shifting incentives."
} 
are very low, since monitoring is basically sine qua non of the proceeding itself, we can conclude, that the probability of monitoring is close to $p=1$.

Under the general theory carrots and sticks are defined as a monetary instrument, which means that they represent a transfer of wealth from the principal (state ${ }^{46}$ to the agent (manager) in the case of carrots, and a transfer of wealth from the agent (manager) to the principal (state) in the case of sticks. Carrots in insolvency law can, in a broader definition, be defined as monetary, ${ }^{47}$ but the transfer of wealth does not come from the principal (state), but from the creditors. This means that carrots are not financed through the general tax system, which was one of the assumptions from De Geest and Dari-Mattiacci (2010). Sticks in the form of imprisonment and of manager disqualification are considered wealthdestroying sticks and are consequently not considered monetary sticks. Only sticks in the form of fines and damages (redistributive sanctions) are considered classical monetary sticks, whereas sticks in the form of damages are not awarded to the principal but to the creditors of the debtor. In the case of debtor in possession rule and in the case of bonuses for managers for the prompt initiation of insolvency proceedings, the transfer of wealth is indirect, as the original transfer of wealth (payment) is made between the debtor (the indebted company) and the manager.

Even though all carrots and some sticks are monetary instruments and even though the probability of ex-post monitoring equals 1, carrots and sticks in insolvency law are two different kinds of instruments (the difference being not only a matter of framing). Firstly, in the case of carrots the wealth transfer is made between the agent and its creditors (and not between the principal and the agent). Secondly, in the case of monetary sticks (fines for misdemeanours or criminal acts), the transfer of wealth is made between the principal (state) and the agent (debtors' management). Finally, sticks are more or less exclusively used in liquidation cases and carrots in reorganization cases. This means that the concept of carrots and sticks rests upon the idea that reorganization proceedings can be successful only if the initiation of the proceedings is in the broad time limits of the definition of timely initiation. As a consequence managers are incentivized to start and successfully complete reorganization proceedings.

Dari-Mattiacci and De Geest (2010) suggest that the threat to punish (a stick) is more powerful than the promise to reward (a carrot) because, when parties comply, the former is not carried out and thus can be reiterated all over again (the multiplication effect), whereas rewards will have to be paid (by someone) and thus are consumed with use. The multiplication effect of sticks is also relevant in insolvency law, as sticks in the case of compliance with the mandatory rules will not be carried out.

\footnotetext{
${ }^{46}$ Principals (the insolvency trustee, courts, state agency) are benevolent, ex-ante not fully informed but ex-post fully informed, with small additional costs.

47 In the case of debtor in possession, the management of the debtor who has filed for a formal financial reorganization procedure remains in office and continues to perform managerial tasks of the debtor's businesses. This means that the manager will not lose his job and will still get paid by the debtor, ultimately by the creditors as the economic owners of an insolvent debtor. Keeping the job and the salary is considered to be the monetary carrot. Deviations of the absolute priority rule means that even though not all creditors are paid in full, the existing shareholder can retain (preserve) a small proportion of shares. The transfer of wealth from creditors to existing shareholders is considered a monetary carrot.
} 
Furthermore, Dari-Mattiacci and De Geest (2013) set three normative guidelines, firstly, that in simple settings sticks are superior because they are not meant to be applied and thus minimize transaction ${ }^{48}$ costs and risks. Their second guideline suggests the employment of carrots in cases of specification problems (i.e. when the lawmaker does not know what to ask from each citizen/agent/principal). ${ }^{49}$ Thirdly, carrots should be employed in the case of singling-out problems (i.e. where the lawmaker needs to ask for substantially greater efforts from some citizens/agents).

We argue that, due to relatively clear legal rules in insolvency, the specification problem does not represent the problematic issue. As a consequence, we also argue that complying with the rules governing the occurrence of insolvency can be understood to be a generally simple setting. Due to the fact that managers are active in business undertakings, there also is no real issue in terms of the singling-out problem, as managers on average have to use approximately the same efforts to monitor the financial status of their company. Managers are generally also the least cost information providers on the company's financial status and debt. Following the general guidelines, sticks should be the superior instrument. But as the analysis has shown that the characteristics of carrots and sticks in insolvency law do differ from the general characteristics of carrots and sticks, general insights might be applied only with the appropriate adjustments.

Specific literature on incentive mechanisms for the prompt initiation of insolvency proceedings shows that sticks have serious shortcomings in cases of closely held private companies, where managers are also shareholders and as a consequence, a significant percentage of a manager's wealth is (might be) tied up in the assets of their companies. Comparative analysis and theory also shows that sticks in the form of civil damages are not efficient, as creditors are reluctant to invest additional money in long, unpredictable litigations. Sticks should, in theory, generate a relatively powerful incentive stream in publicly held companies where managers and shareholders are in the agent-principal relationship. Managers have little reasons to risk tort, misdemeanour, or even criminal liability due to their non-compliance with the duty to promptly begin insolvency proceedings.

Additionally, Dari-Mattiacci and De Geest (2013) identified a tendency in modern legal systems towards the increasing use of carrots. This tendency, as shown in the comparative analysis, can also be seen in insolvency law. General legal and economic insight and specific insolvency literature also shows that carrots should work best in closely held private companies, where managers are also shareholders. The idea that they hold some percentage of shares after the reorganization and that they can perform their managerial position unchanged might well be their value maximizing option/decision. Such managerial value maximizing behaviour might (to a certain extent) well deter/prevent risk-averse managers

\footnotetext{
$\overline{48} \gg$ In addition, sticks cause fewer distributional distortions when the citizens are sufficiently homogenous with respect to effort costs. Yet if citizens are heterogeneous with respect to effort costs than sticks may punish citizens who are unable to comply with the rule at reasonable costs - if they are applied in such setting they generate transaction costs and impose needless risk costs.«

${ }^{49}$ It is suggested to employ carrots when there are specification problems, when it is not clear who exactly should do what (e.g. who should invent, compose, rescue, disclose information). In such cases a stick regime would simply have to be overbroad (both in terms of the citizens from whom it requires an effort and the tasks it requires from the citizens).
} 
from bearing/taking on an inefficient (sub-optimal) level of risk with projects that have a low probability of success but potentially high rewards that might save their business enterprises.

We can sum up that carrots and sticks, when used separately have important disadvantages and that using either of them can have an adverse effect on initiation incentives. In addition, our short comparative analysis shows that in practice, due to a variety of reasons, neither sticks nor carrots really work. As we have proved that carrots and sticks are different instruments, we suggest that carrots and sticks should be used simultaneously and that their combined employment might have an important synergetic effect, which still has to be additionally empirically and comparatively researched.

\section{Conclusion}

This paper seeks to analyse the optimal managerial petition decisions in formal insolvency proceedings and provides a comparative analysis of "sticks versus carrots", used in insolvency laws as an incentive mechanism for managers' prompt proposal of insolvency proceedings. Moreover, this article provides evidence that incentive mechanisms used in compared legal systems strongly differ, from the use of only carrots in the US legal system, to a very strict tort and even criminal liability in the German and French legal systems.

Whether insolvency law should use carrots or sticks in order to trigger the optimal commencement of insolvency proceedings is an important and partially unexplored question. One of the essential goals of insolvency law is the pursuit of ex-ante efficiency. The key element of ex-ante efficiency is a set of incentive mechanisms that induces managers to promptly file a petition triggering a formal insolvency proceeding. Without the prompt initiation of insolvency proceedings, the financial and business deterioration of firms filing for insolvency is already so bad, that any ex-post efficient insolvency proceeding is no longer relevant. Theory suggests that, due to a lack of incentive mechanisms, optimal managerial behaviour can be induced only by law, using either carrots or sticks mechanisms. However, the provided analysis also reveals special, distinctive features of carrots and sticks incentive mechanisms once they have been employed in the domain of insolvency law.

Legal and economic literature on insolvency law supported by the comparative analysis shows that sticks and carrots, when used separately, have important shortcomings and that using either of them can have an adverse effect on initiation incentives. Due to poor results for the prompt initiation of insolvency proceedings in basically all compared legal systems, we suggest the complementary use of a wide variety of carrots and sticks (a combination of them, i.e. a mixed system), while regard should also be given to the idea that regulatory/investigation focus, especially in civil law countries, should be devoted to the identification of additional, alternative initiators of insolvency proceedings, such as banks and/or different public authorities, such as tax administrations or similar institutions with sufficient ex-ante information about the debtor's financial position. Such alternative institutions might well be a partial solution to the problem of ex-ante inefficiencies due to the untimely initiations of the insolvency proceedings. 


\section{References}

Adler, B. E., Capkun, V., Weiss, L. A. (2006). Theory and Evidence on the Bankruptcy Initiation Problem. American Law \& Economics Association Annual Meetings, Paper 53. Adler, B. E., Capkun V., Weiss, L. A. (2013). Value Destruction in the New Era of Chapter 11. The Journal of Law, Economics \& Organization, 29(2), 461-483.

Armour, J. (2001). The Law and Economics of Corporate Insolvency: A Review. ESRC Centre for Business Research, University of Cambridge Working paper, 197.

Baird, D. G., Jackson, T. H. (1984). Possession and Ownership: An Examination of the Scope of Article 9. Stanford Law Review, 35, 175-212.

Baird, D. G. (1991). The Initiation Problem in Bankruptcy. International Review of Law \& Economics, 11(2), 223-232.

Baird, D. G. (1996). A World without Bankruptcy. In Bhandari, J. S., Weiss, L. A. (Ed.). Corporate Insolvency, Economic and legal Perspectives. Cambridge University Press.

Bebchuk, L. A. (2002). Ex ante Costs of Violating Absolute Priority in Bankruptcy. Journal of Finance, 57(1), 445-460.

Bharath, S. T., Panchapakesan V., Werner I. (2007). The Changing Nature of Chapter 11. Working Paper, University of Michigan.

Bowers, J. W., Whither. (1992). What Hits the Fan? Murphy's Law, Bankruptcy Theory, and the Elementary Economics of Loss Distribution. Georgia Law Review, 1, 27-84.

Cabrillo, F., Depoorter, B. W. (2000). Bankruptcy Proceedings. In Bouckaert, B., De Geest, G. (Ed.). Encyclopedia Of Law \& Economics. Cheltenham, Northampton: Edward Elgar and The University Of Ghent.

Cepec, J. (2014). Pravno ekonomska analiza insolvenčnih postopkov. Doctoral thesis, Universtity of Ljubljana, Faculty of Law.

Cepec, J. (2013). Zakaj potrebujemo insolvenčno pravo?: perspektiva ekonomske analize prava. Lexonomica, 5(2), 163-178.

Coase, R. H. (1960). The Problem of Social Cost. Journal of Law and Economics, 3, 1-70. Cooter, R., Ulen T. (2004). Law and Economics (4th ed.). Boston: Pearson.

De Geest, G., Dari-Mattiacci, G. (2010). Carrots, Sticks, and the Multiplication Effect. The Journal of Law, Economics \& Organization, 26(2), 365-384.

De Geest, G., Dari-Mattiacci, G. (2013). The rise of carrots and the decline of sticks. University of Chicago Law Review, 80, 341-392.

Eidenmüller, H. (2006). Trading in Times of Crisis: Formal Insolvency Proceedings, Workouts and the Incentives for Shareholders/Managers. European Business Organization Law Review, 7(1), 239-258.

Euler Hermes Kreditversicherungs-AG. (2006). Zentrum für Insolvenz Universität Mannheim, Ursachen von Insolvenzen Gründe für Unternehmensinsolvenzen aus der sicht Von Insolvenzverwaltern. Wirtschaft Konkret Nr. 414.

Frouté, P. (2007). Theoretical Foundation for a Debtor Friendly Bankruptcy Law in Favour of Creditors. European Journal of Law and Economics, 24(3), 201-214.

Finch, V. (2009). Corporate Insolvency Law, Perspectives and Principles (Second Edition). Cambridge: University Press.

Goode, R. (2011). Principles of Corporate Insolvency Law. London: Sweet \& Maxwell. 
Hart, O. (1999). Different Approaches to Bankruptcy. Harvard Institute of Economic Research Paper No. 1903.

Henderson, M. T. (2007). Paying CEOs in Bankruptcy: Executive Compensation when Agency Costs are Low. Northwestern University Law Review, 101(1), 1543-1619.

International Monetary Fund. (1999). Orderly \& Effective Insolvency Procedures, Key Issues. Legal Department, International Monetary Fund.

Jackson, T. H. (1982). Bankruptcy, Non-Bankruptcy Entitlements and the Creditors' Bargain. Yale Law Journal, 91(5), 857-907.

Jackson, T. H. (1985). Translating Assets and Liabilities to the Bankruptcy Forum. Journal of Legal Studies, 14(1), 73-114.

Jackson, T. H. (2001). The logic and limits of Bankruptcy law. Washington D.C.: Beard Books.

Kennedy, D. S., Bailey, J. S., Clift, R. S. (2000). The Involuntary Bankruptcy Process: A Study of the Relevant Statutory and Procedural Provisions and Related Matters. University of Memphis Law Review, 31, 3-59.

Kramer, R., Peter, F. K. (2012). Insolvenzrecht, Grundkurs für Wirtschaftswissenschaftler. Wiesbaden: Gabler Verlag, Springer Fachmedien.

Lazear, P. E. (1995). Personnel Economics. Boston: MIT Press Books.

Listokin, Y. (2007). Paying for Performance in Bankruptcy: Why CEOs should be compensated with debt. University of Pennsylvania Law Review, 155(4), 777-832.

Madaus, S. (2013). Reconsidering the Shareholder's Role in Corporate Reorganisations under Insolvency Law. International Insolvency Review, 22, 106-117.

Marinč, M., Vlahu, R. (2011). The Economics of Bank Bankruptcy Law. Berlin, Heidelberg: Springer.

Martin, N. (2005). The Role of History and Culture in Developing Bankruptcy and Insolvency Systems: The Perils of Legal Transplantation. Boston College International and Comparative Law Review, 28(1), 1-77.

McCormack, G. (2007). Control and Corporate Rescue: An Anglo-American Evaluation. The International and Comparative Law Quarterly, 56(3), 515-551.

McCormack, G. (2009). Apples and Oranges? Corporate Rescue and Functional Convergence in the US and UK. International Insolvency Review, 18(2), 109-134.

Moss, G. (1998). Chapter 11: An English Lawyer's Critique. Insolvency Intelligence, 11, $17-21$.

Omar, P. (2014). A Reform in Search of a Purpose: French Insolvency Law Changes (Again!). International Insolvency Review, 23(3), 201-220.

Payne, J. (2014). Debt Restructuring in English Law: Lessons from the US and the Need for Reform. University of Oxford, Legal Research Paper Series, Paper No. 89/2013.

Picker, R. C. (1992). Voluntary Petitions and the Creditors' Bargain. University of Cincinnati Law Review, 61(2), 519-542.

Posner, R. A. (2011). Economic analysis of law (8th edition). Austin, Texas; Wolters Kluwer, Law \& Business.

Rasmussen, R. K., Skeel, D. A. (1995). The Economic Analysis of Corporate Insolvency Law. American Insolvency Law Review, 3, 85-115. 
Shavell, S. (2004). Foundations of Economic Analysis of Law. Cambridge, Massachusetts: The Belknap Press of Harvard University Press.

Shu-Acquaye, F. (2011). American Corporate Law: Directors' fiduciary Duties and Liability During Solvency, Insolvency and Bankruptcy in Public Corporations. University Of Puerto Rico Business Law Journal, 2(1), 2011, 1-20.

Skeel, D. A. (2003). The Past, Present and Future of Debtor-in-Possession Financing. Cardozo Law Review, 25(5), 1905-1934.

Skeel, D. A. (2003). Creditors' Ball, The "New" New Corporate Governance in Chapter 11. University of Pennsylvania Law Review, 152(2), 917 -951.

Stiglitz, J. E. (2001). Bankruptcy Laws, Basic Economic Principles. In Claessens et al (Ed.). Resolution of Financial Distress, An International Perspective on the Design of Insolvency Laws (1-24). Washington D.C.: The World Bank.

Sorensen, K. E. (2013). Disqualifying Directors in the EU. Nordic \& European Company Law Working Paper Series, 10-43.

Tabb, C. J. (1997). The Law of Bankruptcy. Westbury, New York: The Foundation Press. Warren, E. (1993). Bankruptcy Policymaking in an Imperfect World. Michigan Law Review, 92(2), 336-387.

Warren, E., Westbrook, W. (2001). The Law of Debtors and Creditors (Fourth Edition). Gaithersburg: Aspen Law \& Business.

Wathne, K. H., Heide, J. B. (2000). Opportunism in Interfirm Relationships: Forms, Outcomes, and Solutions. Journal of Marketing, 64(4), 36-51.

Weber, R. (2006). Can the Sauvegarde Reform Save French Bankruptcy Law: A Comparative Look at Chapter 11 and French Bankruptcy Law from an Agency Cost Perspective Note. Michigan Journal of International Law, 27, 257-302.

Westbrook, W., Booth, C. D., Paulus, C. G., Rajak, H. (2010). A global view of Business Insolvency Systems. Washington, D.C.: The World Bank.

White, M. J. (2001). Bankruptcy Procedure in Countries Undergoing Financial Crises. In Claessens et al (Ed.). Resolution of Financial Distress, An International Perspective on the Design of Insolvency Laws (25-43). Washington D.C.: The World Bank.

White, M.J. (2005). Economic Analysis of Corporate and Personal Bankruptcy Law. National Bureau of Economic Research (NBER) Working Paper 11536.

Wittman, A. D. (1984). Liability for Harm or Restitution for Benefit? Journal of Legal Studies, 13(1), 57-80.

Zajc, K., Cepec, J. (2012). Globalna finančna kriza in novele Zakona o finančnem poslovanju, postopkih zaradi insolventnosti in prisilnem prenehanju. Podjetje in Delo, 38(6/7), 1290-1303.

Zweigert, K., Kötz, H. (2004). An Introduction to Comparative Law. New York: Oxford University Press. 